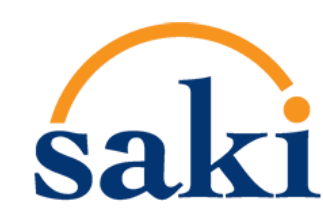

Studi Akuntansi \& Keuangan Indonesia

\title{
Efektivitas Praktikum Mandiri Akuntansi Perusahaan Dagang Berbasis Youtube Selama Covid-19
}

\author{
Ardiansyah \\ Politeknik Negeri Ambon, \\ Jl. Ir. M. Putuhena, Rumah Tiga, Tlk. Ambon, Kota Ambon, Maluku
}

Kata Kunci:

Covid-19, Praktikum,

Pendidikan Akuntansi,

YouTube

Keywords:

Covid-19, Practicum,

Accounting Education,

YouTube.

\section{Corresponding author:} ardi4n.1410@gmail.com

\begin{abstract}
Abstrak
Tujuan penelitian ini adalah untuk menganalisis efektivitas praktikum mandiri yang dilakukan oleh mahasiswa secara online melalui media video YouTube yang dibuat oleh peneliti pada saat covid-19. Jenis penelitian ini kualitatif dengan metode pengumpulan data kuesioner. Subjek penelitian ini adalah mahasiswa D4ABT/2B dan D4ABT/2C Prodi D IV Administrasi Bisnis Terapan, Jurusan Administrasi Niaga, Politeknik Negeri Ambon. Hasil penelitian menunjukkan bahwa video praktikum berbasis YouTube yang dikembangkan peneliti mendapatkan respon yang baik dari mahasiswa dan efektif sebagai media praktikum secara online. Temuan penelitian ini memberikan insight untuk pendidikan akuntansi terutama dosen akuntansi untuk membuat video tutorial praktikum yang diunggah melalui YouTube meskipun perkuliahan nantinya dilakukan secara tatap muka pasca covid-19 sehingga mahasiswa dapat dengan mudah mempelajari kembali kegiatan praktikum yang telah dilakukan.
\end{abstract}

\footnotetext{
Abstract

This study aims to determine the effectiveness of students' independent practicum conducted via the researcher's YouTube during Covid-19. This type of research is descriptive qualitative with data collection methods of questionnaires. This study's subjects were D4ABT / 2B and D4ABT / 2C students of the D IV Applied Business Administration Study Program, Department of Commerce Administration, Ambon State Polytechnic. The results show that the researcher's YouTube-based practicum video received a good response from students and effective as an online practicum media. This finding contributes to accounting education, especially for accounting lecturers, to give insight into making practicum tutorial videos uploaded on YouTube even though lectures are conducted face-to-face teaching at the post-Covid-19 so that students can quickly relearn practicum activities that have been carried out.
} 


\section{saki}

Studi Akuntansi \& Keuangan Indonesia

\section{Pendahuluan}

Upaya memaksimalkan partisipasi mahasiswa dalam proses perkuliahan senantiasa menjadi topik hangat di banyak kesempatan, terutama mahasiswa vokasi yang diharapkan siap kerja didunia industri, sehingga pengembangan politeknik atau pendidikan vokasi disesuaikan dengan kebutuhan pasar kerja dan dunia industri serta memiliki kemampuan terhadap penguasaan teknologi. Pada prinsipnya dosen akuntansi mesti mampu mendesain proses perkuliahan yang berfokus terhadap proses yang dilakukan mahasiswa dalam pembelajaran dan praktikum bukan berfokus kepada proses dosen dalam mentransfer ilmu kepada mahasiswa (Titisari et al., 2013; Irianto, 2019; Nurcahyo et al., 2019; Kirana \& Susilowibowo, 2020).

Proses pembelajaran, training dan praktikum diupayakan dapat mendorong peningkatan keterampilan mahasiswa vokasi dengan berbagai metode yang teruji dan sesuai dengan situasi dan kondisi perguruan tinggi (Ardiansyah, 2020). Selain itu, harus ada langkah serius untuk meningkatkan inovasi terhadap desain pembelajaran dan praktikum agar dapat menghasilkan tenaga terampil, siap kerja dan piawai mengoperasikan teknologi yang didukung oleh kemampuan dosen (Irianto, 2019; Ardiansyah, 2020). Upaya kolaborasi teknologi dan pendidikan dalam satu rangkaian siklus tentunya, menjadi harapan berbagai elemen pendidikan agar efiesien dari sisi biaya sekaligus meningkatkan produktivitas (Nurcahyo et al., 2019).

Strategi dan metode praktikum online tepat sasaran dan yang murah menjadi pekerjaan rumah setiap dosen untuk merumuskannya sesuai bidang keahlian masing-masing termasuk mata kuliah akuntansi. Menurut Dewi et al. (2020) bahwa keunggulan perkuliahan online dalam hal fleksibilitas yang memungkinkan mahasiswa meningkatkan motivasi belajar dalam penyerapan materi pada situasi yang lebih kondusif. Berbicara akuntansi tidak akan terlepas antara sisi teori dan sisi praktikum karena akuntansi akan lebih mudah dimengerti dengan praktik analisis, pencatatan, dan penjurnalan secara langsung. Oleh karena itu, proses pengembangan metode praktikum akuntansi yang tepat merupakan upaya untuk meningkatkan kualitas dan kreatifitas serta merupakan proses pembiasaan mahasiswa terhadap implementasi teknologi (Titisari, 2013; Latifah \& Susilowati, 2019). 


\section{saki}

Studi Akuntansi \& Keuangan Indonesia

Salah satu wujud implementasi teknologi dalam proses pembelajaran dan praktikum akuntansi adalah video tutorial. Video merupakan media untuk menyampaikan materi perkuliahan dan praktikum kepada mahasiswa yang efektif dan terpopuler (Zhang et al., 2006; Guo et al., 2014; Rotellar \& Cain, 2016; Luhsasi \& Sadjiarto, 2017; Mischel, 2018; Yusri et al., 2018; Ruski dan Sholeh, 2019; Samosir et al., 2019). Video pembelajaran yang dapat diakses secara bebas oleh mahasiswa adalah melalui platform YouTube. Melalui YouTube mahasiswa dapat langsung melihat dan mendengar penjelasan dosen dan merupakan sarana yang efektif dalam memberikan tutorial praktikum kepada mahasiswa khususnya mata kuliah akuntansi pada topik akuntansi perusahaan dagang. Sehingga menjadi tepat sasaran dalam proses transfer ilmu dari dosen kepada mahasiswa.

Sejumlah penelitian tentang video pembelajaran yang telah dilaksanakan sebelumnya oleh Zhang et al. (2006), Guo et al. (2014), Mischel (2018) dan penelitian lainnya yang khusus membahas video YouTube oleh Luhsasi \& Sadjiarto (2017), Yusri et al., (2018), Ruski dan Sholeh (2019), Samosir et al., (2019) berorientasi membahas penggunaan YouTube dalam mengasah keterampilan seni dan soft skill mahasiswa, namun ada 2 (dua) hal berbeda dari penelitian-penelitian tersebut sehingga, penelitian ini menjadi penting untuk dilakukan, yaitu; pertama, masih sedikit penelitian yang membahas video pembelajaran pada subjek materi akuntansi. Oleh karena itu, masih diperlukannya pengetahuan lebih lanjut tentang efektivitas pembelajaran praktikum akuntansi berbasis video YouTube. Kedua, penelitian-penelitian terdahulu dilakukan pada pra covid-19 atau kondisi normal sebelum pandemi global yang tentu situasi dan kondisi pengambilan data penelitian terhadap perkuliahan pada pra covid-19 berbeda 360 derajat dengan saat terjadi pandemi covid-19 baik situasi maupun mental subjek penelitian yang turut mempengaruhi proses pengambilan data penelitian.

Dalam penelitian ini peneliti sebagai dosen yang mengampu mata kuliah akuntansi perusahaan dagang membuat video tutorial praktikum untuk di unggah via YouTube agar dapat diakses oleh mahasiswa dengan memperhatikan faktor-faktor tercapainya efektivitas video pembelajaran dan praktikum berbasis YouTube, seperti kualitas gambar yang dapat disesuaikan dengan sinyal internet masing-masing mahasiswa dengan demikian, aspek murah dapat terpenuhi. Berdasarkan latar belakang tersebut, maka penelitian ini bertujuan untuk mengetahui efektivitas praktikum mandiri yang 


\section{saki}

Studi Akuntansi \& Keuangan Indonesia

dilakukan oleh mahasiswa secara online melalui media video YouTube yang dibuat oleh peneliti pada saat covid-19. Kontribusi praktis penelitian ini adalah memberikan insight kepada penyelenggara pendidikan akuntansi pada umumnya dan dosen pengampu mata kuliah praktikum akuntansi pada khususnya untuk penyelenggaraan model praktikum mandiri akuntansi perusahaan dagang pasca covid-19 berbasis YouTube.

\section{Telaah Literatur}

Pada kompetisi dunia kerja yang semakin ketat dewasa ini, proses pembelajaran yang kreatif dan terbarukan atas kolaborasi teori dan praktik di perguruan tinggi menjadi sesuatu yang vital (Taufiq, 2015; Irianto, 2019; Nurcahyo et al., 2019; Ardiansyah, 2020). Oleh karena itu, perlunya metode efektif praktikum akuntansi terutama di masa Covid-19, salah satunya dengan pembelajaran secara elektronik.

Menurut Wahono (2012) dalam Agustina (2013) bahwa dalam proses pembelajaran secara elektronik memiliki karakteristik terdiri dari: (a) Non Linearity, adanya kebebasan dalam mengakses objek pembelajaran dan tersedianya fasilitas dalam memberikan persyaratan sesuai pengetahuan pengguna; (2) Self managing, dosen dapat melakukan pengelolaan secara mandiri dalam proses perkuliahan sesuai mekanisme yang telah ditentukan; (3) Feedback interactivity, adanya fasilitas agar perkuliahan dapat dilakukan dengan interaktif; (4) Multimedia learners style, dengan memanfaatkan multimedia, pengguna dapat memahami informasi yang disampaikan secara jelas sesuai kebutuhan pembelajaran; (5) Just in time, e-learning tersedia setiap saat sesuai kebutuhan pemakai, untuk menyelesaikan masalah atau hanya untuk menambah pengetahuan dan keterampilan; (6) Dynamic updating, mempunyai kemampuan memperbaharui isi materi secara online pada perubahan yang terbaru; (7) Acces Ease, hanya menggunakan browser dan; (7) Collaborative Learning, dengan fitur pembelajaran dapat saling interaksi pada waktu yang bersamaan atau berkomunikasi pada waktu yang berbeda.

Video pembelajaran yang tersedia di YouTube dapat dijadikan alternatif sebagai salah satu metode pembelajaran elektronik selama masa Pandemi Covid-19. Hasil penelitian Zhang et al.(2006) menyatakan bahwa video e-learning diakui efektif dalam mendorong tercapainya tujuan pembelajaran 


\section{saki}

Studi Akuntansi \& Keuangan Indonesia

tetapi tidak dapat diklaim bahwa video lebih unggul jika dibandingkan dengan perkuliahan konvensional secara klasikal. Temuan ini didukung oleh hasil penelitian Luhsasi \& Sadjiarto (2017) bahwa produk video pembelajaran berbasis YouTube layak digunakan sebagai media pembelajaran ekonomi akuntansi. Intensitas pemakaian gadget dikalangan mahasiswa yang terhubung internet pun terbilang cukup tinggi seperti membuka aplikasi YouTube (Samosir et al., 2019). YouTube menjadi aplikasi yang familiar di kalangan mahasiswa salah satunya sebagai rujukan belajar secara online. Hal ini didukung oleh temuan Yusri et al., (2018) yang menyatakan bahwa penggunaan media YouTube berpengaruh terhadap peningkatan motivasi belajar Bahasa Inggris siswa.

Menurut Aydin \& Gumus (2016) yang meneliti tentang proses pengembangan tim dalam kegiatan pembelajaran online di Turki menunjukkan bahwa mahasiswa yang mengikuti kegiatan pembelajaran online lebih memilih kegiatan pembelajaran dilakukan secara individu daripada dilakukan secara tim. Hal ini tentu sesuai dengan kondisi covid-19 dimana mahasiswa dimotivasi untuk mampu belajar secara mandiri dan memaksimalkan media-media pembelajaran berbasis digital. Tercapainya keberhasilan atau efektivitas pembelajaran yang dilakukan secara online mesti ada keseriusan yang sama antara dosen dengan mahasiswa yang salah satu metodenya adalah berlangsungnya interaksi dua arah. Pandemi Covid-19 yang merupakan pandemi global menjadi titik awal konvergensi dari pola dan gaya konvensional ke arah digitalisasi termasuk aktivitas pembelajaran dan praktikum di tingkat politeknik. Praktikum sebagai salah satu program andalan pendidikan vokasi dalam mencetak lulusan yang siap terjun ke dunia industri harus tetap berlangsung dalam kondisi apapun.

\section{Metode Penelitian}

\section{Jenis Penelitian}

Jenis penelitian ini adalah kualitatif. Adapun alasan peneliti memilih jenis penelitian kualitatif untuk mencapai tujuan penelitian yaitu: (1) Data penelitian dapat dianalisis secara induktif (Jailani, 2013), dengan demikian peluang peneliti cukup besar dalam mengungkapkan fakta-fakta jamak dalam 


\section{saki}

Studi Akuntansi \& Keuangan Indonesia

data dan keterkaitannya dengan subjek penelitian lebih eksplisit; (2) Karakter penelitian subyektif (Chariri, 2009), peneliti dapat langsung berinteraksi dengan subjek penelitian; (3) Kaya akan temuan yang kompleks, paripurna dan detail (Chariri, 2009), karena didasarkan gambaran subjek yang rinci dan jelas; dan (4) Memungkinkan antara peneliti dan subjek penelitian melakukan diskusi akan hasil penelitian (Jailani, 2013). Dengan tujuan menjawab permasalahan yang diungkapkan dalam penelitian dan berkontribusi baik secara praktis maupun teoritis.

\section{Sampel Penelitian}

Sampel penelitian ini adalah mahasiswa Program Studi (Prodi) D IV Administrasi Bisnis Terapan (ABT), Jurusan Administrasi Niaga, Politeknik Negeri Ambon yang terdiri dari 2 (dua) kelas yaitu kelas D4ABT/2B dan D4ABT/2C pada mata kuliah akuntansi dagang semester genap 2019-2020 dengan total 41 responden. Peneliti memahami bahwa hasil penelitian ini tidak dapatnya digeneralisasi karena merupakan penelitian kualitatif. Oleh karena itu, sebagai solusinya peneliti mengutamakan transferabilitas, yang berarti pada waktu dan situasi tertentu dapat berlaku dan diberlakukan pada situasi lain, jika situasi yang dimaksudkan itu terdapat karakteristik dengan subyek atau situasi yang diteliti (Afiyanti, 2008).

\section{Metode Pengumpulan Data}

Dalam proses pengumpulan data penelitian, peneliti memanfaatkan sumber data kuesioner. Metode pengumpulan data yang digunakan melalui kuesioner untuk pertanyaan tertutup dan terbuka yang didistribusikan secara online dengan metode purposive sampling. Menurut Afiyanti (2008) bahwa pengambilan sampel dalam peneliti kualitatif dilakukan secara sengaja (purposive sampling) dan dititikberatkan pada sektor yang tipikal serta esensial berdasarkan pemahaman konseptual terhadap karakteristik subjek. Pengumpulan data melalui kuesioner cukup populer dalam penelitian akuntansi yaitu sebesar 23\% mulai tahun 2012 sampai 2014 (Hutagalung \& Utomo, 2017).

\section{Analisis Data Penelitian}




\section{saki}

Studi Akuntansi \& Keuangan Indonesia

Data yang berhasil dikumpulkan dianalisis secara deskriptif untuk mengetahui respon mahasiswa terhadap video praktikum mata kuliah akuntansi perusahaan dagang yang diakses melalui YouTube. Data yang telah dikumpulkan selanjutnya dianalisis berdasarkan paradigma interpretivisme (interpretive paradigm). Menurut Hartono (2012) bahwa, interpretive paradigm lebih mengutamakan interpretasi atau pemaknaan seseorang terhadap sebuah simbol yang dalam hal ini akuntansi. Dalam penelitian ini subjek dipandang sebagai realitas sosial yang berupa label, angka, konsep yang lahir dari proses interaksi manusia sekaligus menyatu dengan nilai internal manusia. Menurut Darmayasa \& Aneswari (2015) bahwa paradigma interpretif merupakan metode yang tepat atas suatu praktik akuntansi yang berkaitan dengan manusia, budaya dan agama.

Berikut ini alasan peneliti memilih paradigma interpretif untuk mencapai tujuan penelitian yaitu, sebagai berikut: (1) Data penelitian dapat dianalisis secara induktif (Nurhayati, 2015). Sehingga hubungan peneliti dengan subjek menjadi lebih eksplisit dan bukan sebagai orang asing (Bachri, 2010). Adapun dalam proses analisis dimulai dari sesuatu yang umum mengarah hal yang lebih khusus agar peneliti memiliki peluang dalam mengungkapkan fakta-fakta jamak dari data penelitian dan keterkaitannya dengan subjek; (2) Manusia sebagai instrumen atau alat penelitian baik peneliti maupun subjek (Nurhayati, 2015). Untuk menghasilkan persepsi, perspektif dan penjelasan terkait peristiwa sosial yang terjadi sehingga peneliti dapat mengungkapkan mekanisme interpretasi dan makna apa saja yang terkandung pada suatu lingkungan sosial (Chariri, 2009); (3) Karakter penelitian subjektif (Djasuli, 2017) dan terbatas pada subjek tertentu saja (Bachri, 2010). Sehingga peneliti dapat langsung berinteraksi dengan subjek penelitian agar kaya akan temuan yang kompleks, paripurna dan detail karena didasarkan gambaran subjek yang rinci dan jelas; (4) Memungkinkan peneliti melakukan diskusi dan terlibat aktif dengan subjek penelitian untuk memperoleh kebenaran (Nurhayati, 2015). Sebagai upaya menjawab dan menguraikan permasalahan dalam penelitian, sehingga dapat memberikan kontribusi baik secara praktis maupun teoritis; (5) Dapat mengungkapkan pengetahuan yang tersembunyi dari sebuah peristiwa, fenomena, kejadian, ataupun tindakan atas fakta terdalam (Djasuli, 2017). Sehingga dapat diungkapkan makna dibalik sebuah angka, tindakan, ataupun sikap dan perilaku manusia. 


\section{saki}

Studi Akuntansi dan Keuangan Indonesia, Vol. 3, No. 2, 2020 | E-ISSN: 2654-6221

Studi Akuntansi \& Keuangan Indonesia

Menurut Djasuli (2017) bahwa paradigma interpretif dalam bidang akuntansi sebagai solusi ketidakmampuan paradigma positif dalam mengungkapkan sebuah kejujuran atas praktik akuntansi. Pada paradigma positif yang menganalisis dengan model matematika secara numerik dan menggeneralisasi segala hal sehingga dapat mengakibatkan hasil riset yang tidak dapat menyelesaikan masalah dalam praktik akuntansi. Namun, dalam paradigma interpretif memposisikan manusia sebagai proses sosial atas terbentuknya kondisi sosial itu sendiri.

\section{Hasil dan Diskusi}

\section{Kondisi Umum Responden}

Mahasiswa yang berada di wilayah Pemerintahan Kota Ambon yang bertempat tinggal di rumah orang tua sebanyak 26 orang $(63,4 \%)$, rumah saudara sebanyak 4 orang $(9,8 \%)$, rumah sendiri sebanyak 3 orang $(7,3 \%)$, dan bertempat tinggal di kos sebanyak 8 orang (19,5\%). Adapun perangkat/alat yang digunakan mahasiswa dalam mengikuti praktikum online sebagian besar menggunakan handphone sedangkan pembagian lainnya dapat dilihat pada grafik 1 .

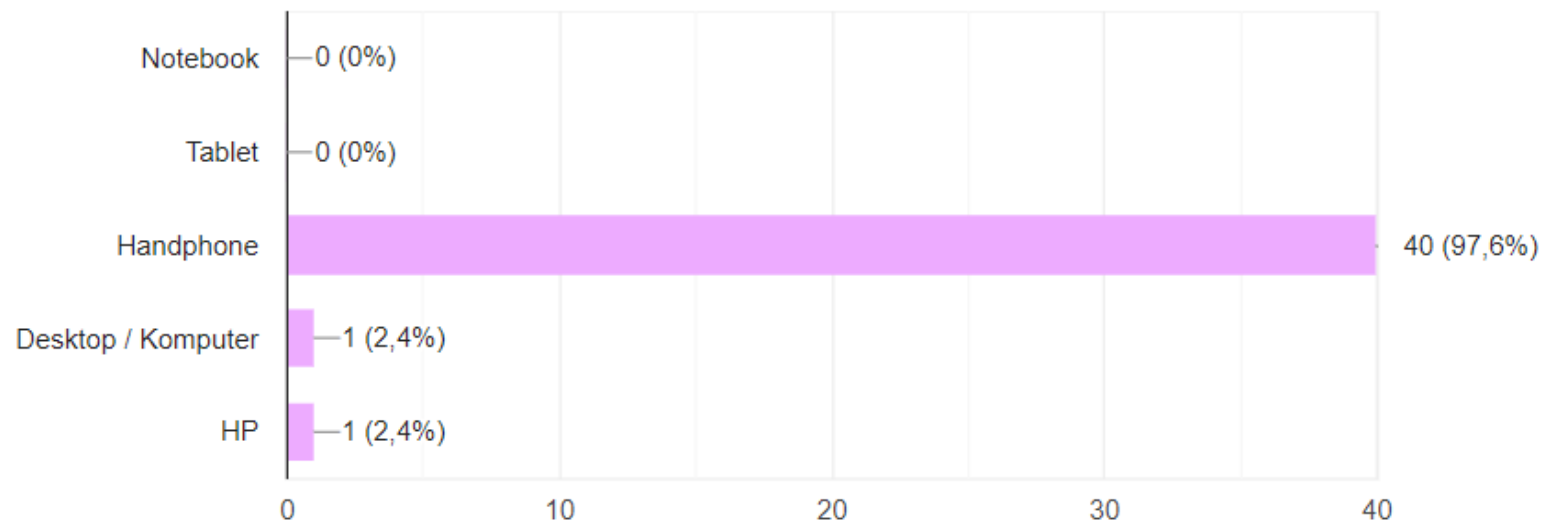

Grafik 1. Perangkat/Alat

Disamping itu koneksi internet juga merupakan salah satu faktor utama yang harus dipenuhi dalam mengikuti praktikum secara online menunjukkan bawah kebanyakan mahasiswa menggunakan internet HP yang pembagiannya secara rinci dapat dilihat pada grafik 2 . 


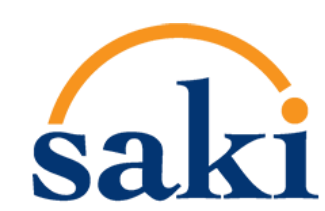

Studi Akuntansi \& Keuangan Indonesia

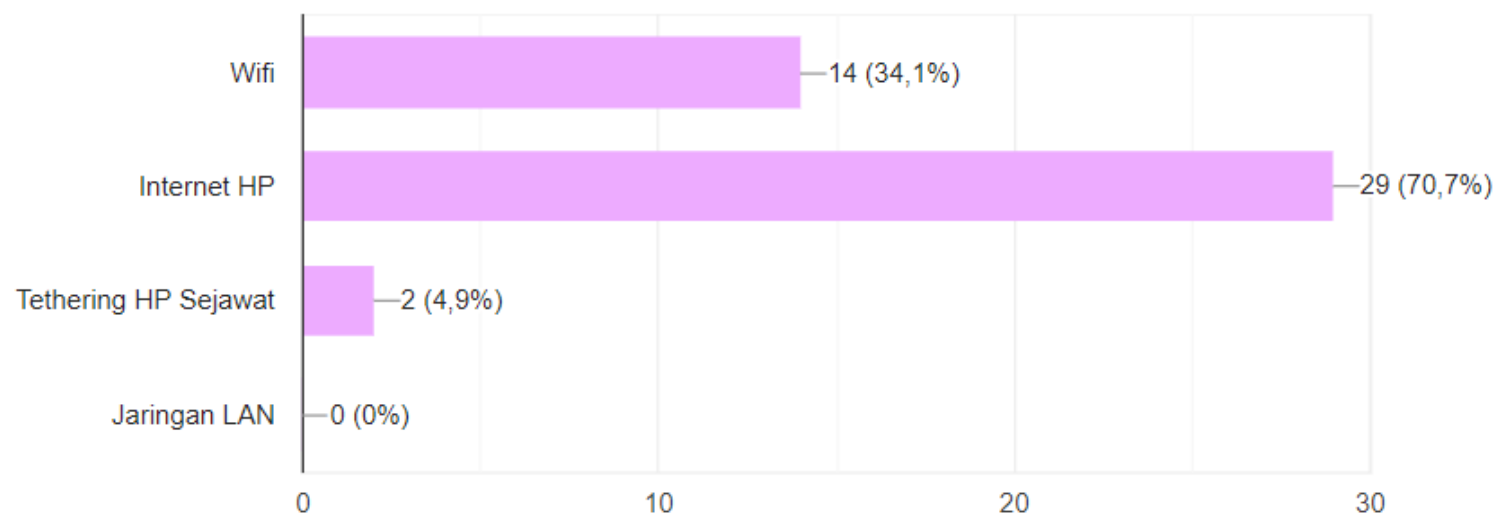

Grafik 2. Koneksi Internet

Meskipun, sebagian besar menggunakan internet HP tidak menjamin kondisi internetnya cepat dan kuat. Hal ini juga dapat dilihat dari persentase kesiapan mahasiswa pada diagram 1 dimana, sebagian besar mahasiswa kurang siap dengan alasan jaringan internet tidak stabil dan kuota tidak cukup. Pertanyaan tentang kesiapan mahasiswa ini multiple choice.

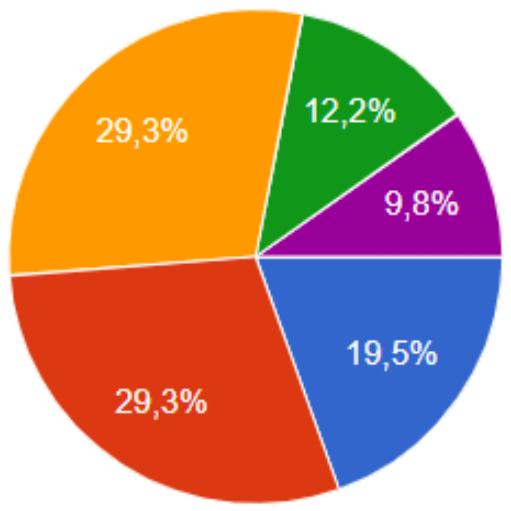

Siap - Internet Cepat

Siap - Kouta Cukup

Kurang Siap - Jaringan Internet Tidak Stabil

Kurang Siap - Kouta Tidak Cukup

Kurang Siap - Jaringan Internet Tidak Stabil dan Kouta Tidak Cukup

\section{Diagram 1. Kesiapan Mahasiswa}

Secara umum pada kondisi pandemi covid-19 yang tidak ada pilihan lain terkecuali aktivitas perkuliahan dan praktikum dilakukan secara online merupakan suatu keadaan yang mahasiswa terdorong untuk beradaptasi secara cepat terhadap lebih dari 1 (satu) media pembelajaran termasuk YouTube. 


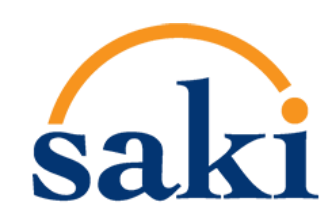

Studi Akuntansi \& Keuangan Indonesia

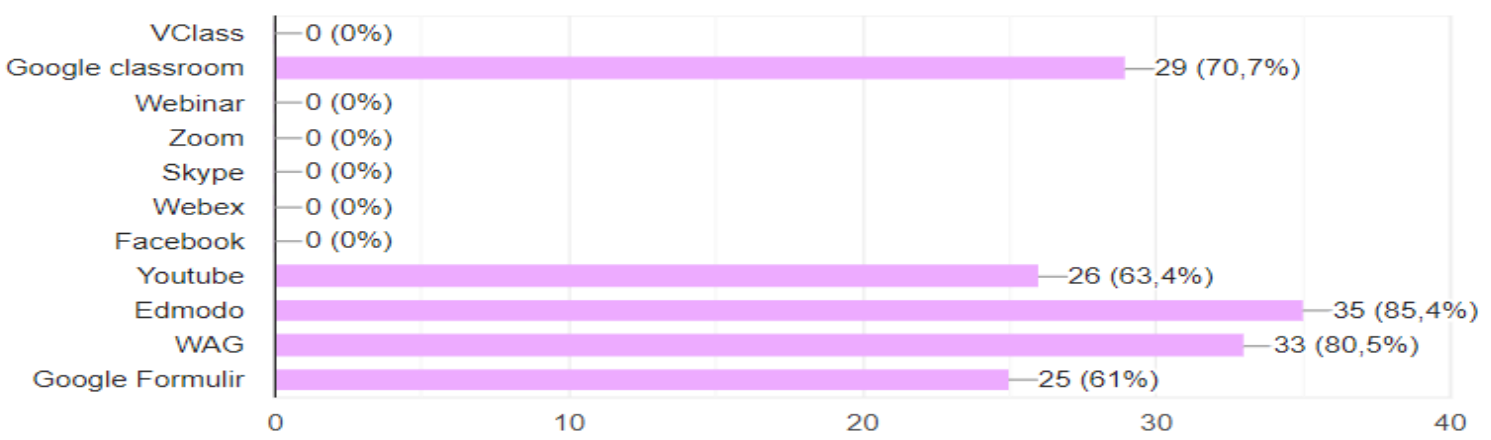

Grafik 3. Media Pembelajaran

\section{Kekurangan Kuliah Online}

Kuliah online yang dimakasud pada penelitian ini adalah kuliah dengan media pembelajaran video YouTube yang dibuat oleh peneliti. Mahasiswa secara mandiri mempelajari bahan praktikum mata kuliah akuntansi perusahaan dagang yang sudah diunggah oleh peneliti sebagai dosen pengampu mata kuliah. Pada pertanyaan ini mahasiswa diperbolehkan memilih lebih dari satu pilihan. Kekurangan keliah online menurut mahasiswa adal bahwa jaringan internet kadang tidak stabil sebagai kekurangan. Kendala jaringan atau sinyal merupakan kekurangan perkuliahan online yang bersifat nasional dan global. Pada urutan kedua terbesar adalah beban tugas yang berlebihan atau tugas yang banyak seperti yang tercantum pada grafik 4 .

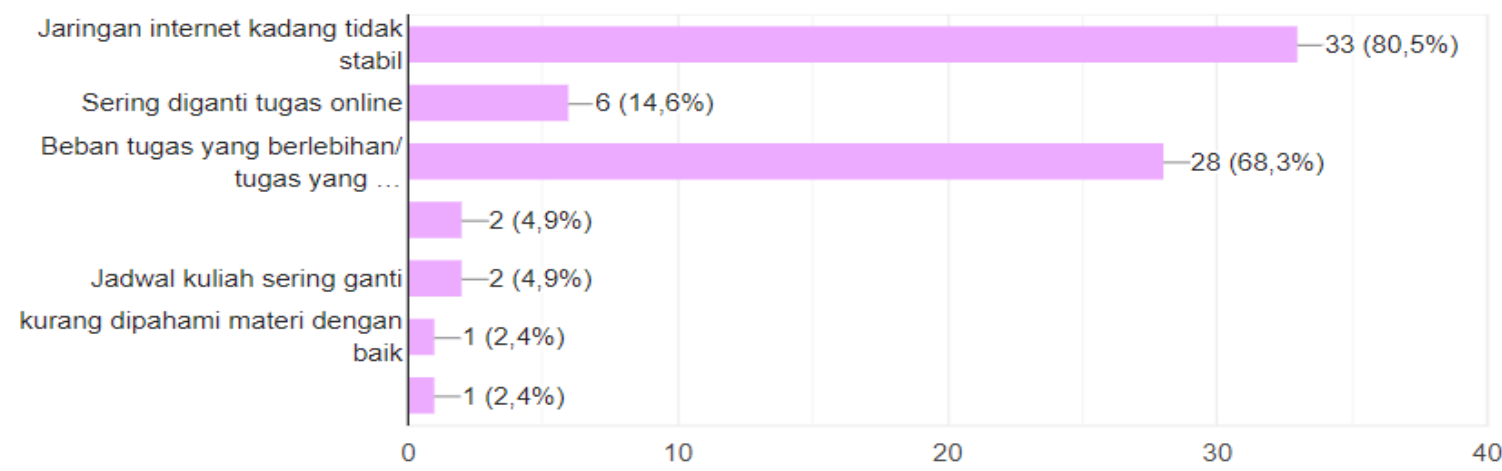

\section{Grafik 4. Kekurangan Kuliah Online}

Selama satu semester di beberapa pertemuan, peneliti juga menerima keluhan yang sama dari para mahasiswa bahwa meskipun penyedia jasa telekomunikasi (provider) dan masih berada di 


\section{saki}

Studi Akuntansi \& Keuangan Indonesia

wilayah Pemerintahan Kota Ambon antara mahasiswa yang satu dengan mahasiswa yang lainnya, tetapi perbedaan titik koordinat tempat tinggal mahasiswa dan pengaruh cuaca yang terkadang sinyal tidak stabil yang pada saat tertentu cepat dan terkadang lambat. Sebagaimana yang dikatakan mahasiswa bahwa

"Kurang baik, karena jika wifi mati maka harus menggunakan data, dan data juga terbatas".

Deadline dalam pengumpulan tugas dan hasil dari pekerjaan praktikum setiap mahasiswa diatur oleh peneliti sesuai situasi dan kondisi serta informasi dari mahasiswa terkait kekuatan sinyalnya masing-masing disaat deadline. Selain itu, kekurangan atau kelemahan praktikum yang dilaksanakan melalui video tutorial berbasis yotube adalah mahasiswa tidak dapat bertanya secara langsung kepada dosen.

"Menurut saya, kelemahannya yaitu pada saat materi yang diberikan ditonton, hal yang tidak dimengerti tidak bisa langsung didiskusikan dengan dosen atau teman kuliah. Berbeda dengan mendapatkan materi tatap muka langsung".

Fitur komentar disediakan oleh YouTube di setiap postingan video bagi mahasiswa yang ingin bertanya secara langsung kepada dosen belum termanfaatkan. Oleh karena itu, salah satu solusi terbaiknya adanya kesempatan yang diberikan oleh dosen kepada mahasiswa untuk bertanya via video call whatsapp selama masih dalam rentang jam perkuliahan. Dengan demikian kebutuhan akan berkomunikasi atau berdiskusi secara langsung dengan dosen dapat terpenuhi dengan maksimal secara virtual.

\section{Efektivitas dan Kelebihan Video Praktikum Via YouTube}

Pada pertanyaan ini mahasiswa diperbolehkan memilih lebih dari satu pilihan. Sebagian besar mahasiswa menjawab bahwa kelebihan kuliah online adalah memperoleh pengalaman baru, hal ini dapat dirasakan dalam bentuk penggunaan teknologi yang secara cepat dan global sehingga setiap mahasiswa mengupayakan dirinya mampu mengoperasikan aplikasi-aplikasi kuliah online yang ditentukan setiap dosen pengampu mata kuliah. Khusus pada mata kuliah akuntansi dagang yang mengkombinasikan antara penggunaan whatsapp group, google form dan YouTube. 


\section{saki}

Studi Akuntansi \& Keuangan Indonesia

Penerapan aplikasi tersebut untuk menunjang proses kelancaran perkuliahan online dan khusus untuk petunjuk atau tutorial praktikum disampaikan dalam media video yang dapat diakses mahasiswa via YouTube. Feedback beberapa mahasiswa melalui kuesioner terkait kelebihan video praktikum via YouTube, sebagai berikut:

"Sangat Baik. Video YouTube yang di berikan dosen, memakai bahasa yang mudah di mengerti oleh saya dan cara penjelasan melalui YouTube juga sangat pelan dan jelas".

"Kelebihannya saya dapat memutar kembali setiap langkah cara kerja dari dosen. Saya dapat teliti setiap titik atau koma cara penulisan dari Akuntansi. Bahkan saya sangat lebih paham setiap kata atau penjelasan dari dosen dengan memutar kembali videonya".

Video yang dibuat peneliti didesain dengan konsep lebih menarik seperti yang dirasakan oleh subjek bahwa:

\section{"Sangat kreatif didukung dengan gambar-gambar menarik".}

Hal ini sejalan dengan temuan Zhang et al.(2006) dan Guo et al. (2014) yang menyatakan bahwa video yang menarik dan dibuat dalam durasi yang pendek setiap video akan menghindari kejenuhan bagi mahasiswa. Hal tersebut dapat dirasakan perbedaan daya tarik antara video praktikum akuntansi dengan susunan angka-angka dan perhitungan yang rumit tentunya akan lebih menguras energi mahasiswa dibandingkan dengan video hiburan yang membuat penonton betah dalam waktu yang relatif lama.

"Sangat baik, dikarenakan materinya terdokumentasi dan dapat diulang-ulang untuk bisa lebih memahami materinya"

"Kelebihannya yaitu penyajiannya terstruktur, penjelasannya sangat bagus serta didukung dengan video yang sudah diedit dengan sangat baik"

"Menurut saya adalah di masa pandemi ini kelebihan vidio pembelajaran berguna untuk kita pelajari di rumah dan bisa menjaga jarak dengan orang lain"

"Materi yang disampaikan melalui chanel YouTube bisa dipahami jika ditoton berkali-kali,dengan kualitas jaringan internet yang baik, maka akan cepat ditangkap materinya, tetapi sebaliknya, jika kualitas internetnnya jelek maka akan menghambat proses pemahaman saya, ditambah lagi dengan waktu perkuliaahan yang terbatas. Maka untuk memahaminya bisa saya lakukan dengan mengunduh videonya lalu ditonton kembali saat waktu saya senggang diluar waktu perkuliahan". 


\section{saki}

Studi Akuntansi dan Keuangan Indonesia, Vol. 3, No. 2, 2020 | E-ISSN: 2654-6221

Studi Akuntansi \& Keuangan Indonesia

"Menurut saya: Kelebihannya Materi yang bapak buat dalam video menggunakan tampilan slide dengan gambar-gambar dan kata-kata yang bisa langsung di pahami, karena sesuai dengan materi yang di ajarkan".

Disamping itu, mahasiswa yang sebelumnya tidak pernah komentar di YouTube maka melalui praktikum online terpicu untuk memberikan komentar dan bertanya melalui whatsapp group dan terkadang ada mahasiswa yang chat whatsapp secara pribadi. Demikian pula bagi mahasiswa yang sebelumnya tidak pernah mengikuti menggunakan zoom, google meet, google classroom, google form, dan aplikasi pembelajaran daring lainnya serta berpartisipasi dalam kelas virtual tersebut menjadi terdorong oleh situasi dan kondisi yang memang harus dilakukan secara daring (dalam jaringan). Sedangkan sisanya terbagi-bagi ke dalam klasifikasi jawaban seperti: tidak perlu ke kampus dan materi terdokumentasi yang dapat dilihat pada grafik 5 .

Dengan tersedianya video praktikum mendorong pembelajaran yang efektif, terlebih lagi dapat diakses di YouTube dimana sebagian besar mahasiswa memiliki kecenderungan mengakses YouTube untuk menggali informasi-informasi terkini baik hanya untuk tujuan hiburan maupun knowledge. Menurut Zhang et al., (2006) bahwa media pembelajaran memiliki fungsi untuk menarik minat dan memotivasi siswa untuk mempelajari sesuatu. Termasuk dalam hal ini, merancang media pembelajaran yang berbasis teknologi sehingga memiliki kesan up-to-date dan terkini sesuai perkembangan zaman yang serba digital. Sekaligus meminimalisir penyalahgunaan elektronik bagi mahasiswa (Eastman, et al., 2008).

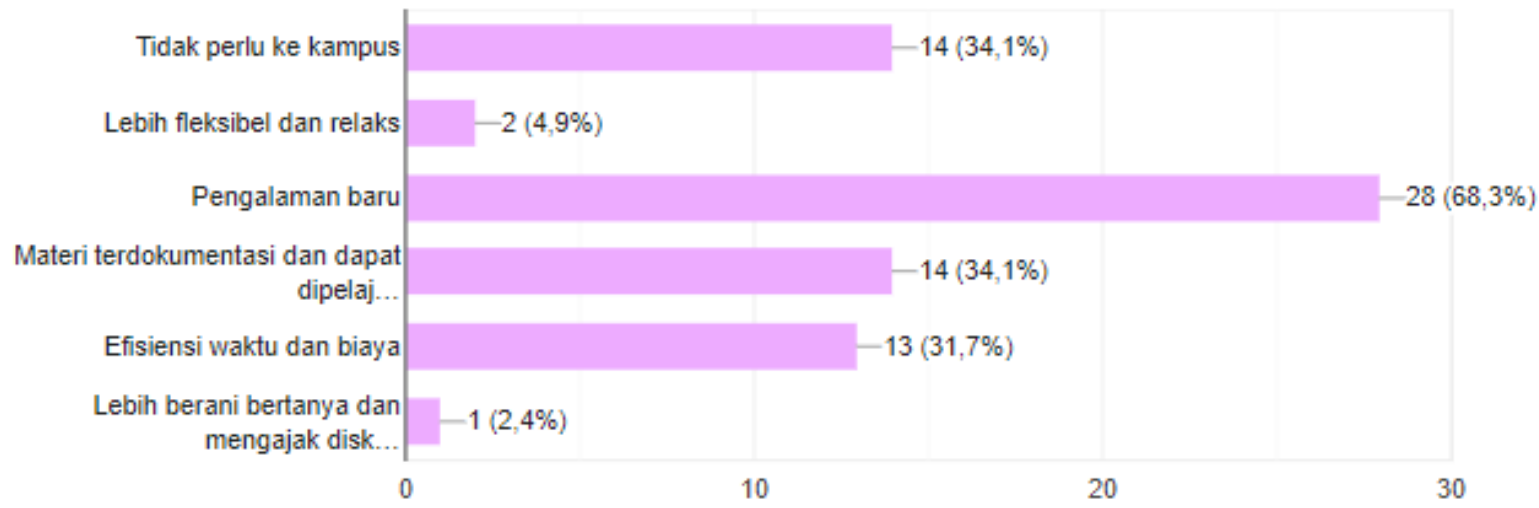

Grafik 5. Kelebihan kuliah online 


\section{saki}

Studi Akuntansi \& Keuangan Indonesia

Pembuatan video praktikum dipandang efektif sebagai media pembelajaran bagi mahasiswa karena mahasiswa dapat mengulang kembali dan menyimak penjelasan dosen. Termasuk dalam perhitungan angka-angka dan kegiatan pencatatan seperti; jurnal umum, jurnal pembelian, jurnal penjualan, jurnal penerimaan kas, dan jurnal pengeluaran kas yang jika mahasiswa hanya membaca teks dan contoh soal di buku petunjuk praktikum akan mengalami kendala yang cukup berat karena tidak ada penjelasan.

Menurut Kesuma (2014) efektivitas pembelajaran merupakan kemampuan untuk mencapai target yang juga terkait dengan bagaimana hasil diperoleh, manfaat atas tercapainya tujuan pembelajaran dan termasuk bagaimana respon peserta didik terhadap usaha yang dilakukan dalam mencapai target pembelajaran tersebut. Sedangkan untuk menilai tingkat efektivitas suatu proses pembelajaran dapat dilihat dari respon peserta seperti merasa senang, puas dengan cara yang digunakan, memberi kesan yang menarik, fasilitas yang mumpuni dan pengajar yang profesional.

Temuan pada penelitian ini sejalan dengan hasil penelitian yang dilakukan oleh Luhsasi \& Sadjiarto (2017), Yusri et al. (2018) dan Samosir et al.(2019). Menurut Guo et al. (2014), bahwa media pembelajaran YouTube dapat mendistribusikan video instruksional dalam skala besar.

Melalui video mampu meningkatkan karakter dan kemampuan siswa dalam menggunakan teknologi informasi (Ruski \& Sholeh, 2019). Disamping itu siswa lebih termotivasi dalam belajar (Guo et al., 2014; Ruski \& Sholeh, 2019). Demikian pula temuan Zhang et al. (2006) dan Mischel (2018), bahwa penggunaan video tutorial sangat penting untuk melengkapi sarana pembelajaran online dan meraih respon yang baik dari mahasiswa.

\section{Media Praktikum Mandiri Akuntansi Perusahaan Dagang Pasca Covid-19}

Secara umum jika, mahasiswa diminta untuk memilih antara praktikum via YouTube dengan praktikum secara konvensional klasikal face to face, maka hanya sedikit mahasiswa memilih praktikum via YouTube hal ini dapat dilihat pada diagram 2 yang menunjukkan persentase yang sangat besar untuk bagian yang berwarna biru. Hal ini menunjukkan bahwa mahasiswa lebih memilih praktikum secara langsung di kampus jika kondisi sudah normal kembali karena faktor utama 


\section{saki}

Studi Akuntansi dan Keuangan Indonesia, Vol. 3, No. 2, 2020 | E-ISSN: 2654-6221

Studi Akuntansi \& Keuangan Indonesia

hambatannya adalah akses internet yang terkadang kurang stabil. Seperti pernyataan mahasiswa ini bahwa

"Kelemahannya. Yang sering saya alami pada jaringan yang lemot/lama. Terhalang dari kapasitas handphone yang sedikit."

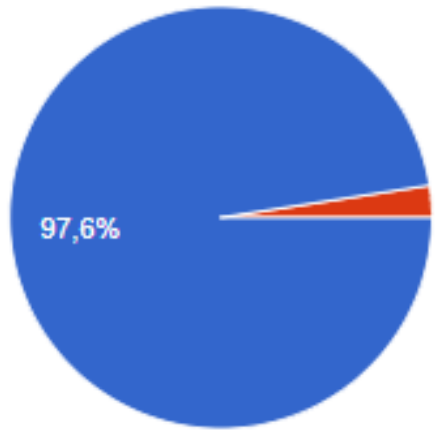

\section{Diagram 2. Praktikum via YouTube Vs Praktikum Konvenssional}

Dengan demikian, mahasiswa lebih memilih perkuliahan dilakukan di kampus secara offline termasuk praktikum mata kuliah akuntansi dagang yang salah satu alasannya adalah waktu.

"Menurut saya, mendengarkan langsung penjelasan dosen di kelas dan melalui video sama-sama baik, hanya ada kendala dalam durasi waktu saja pak".

Pada kondisi pandemi covid-19 maka, metode praktikum yang disampaikan oleh dosen yang dalam hal ini sekaligus sebagai peneliti merupakan salah satu alternatif terbaik. Dengan adanya video berbasis YouTube mahasiswa dapat menyimak kembali dari tutorial praktikum jika masih ada yang belum dimengerti. Adapun waktu untuk menonton video (menyimak video praktikum) dapat disesuaikan dengan kondisi sinyal daerah domisili setiap mahasiswa. Hal tersebut diakui oleh mahasiswa bahwa

"Dua-duanya sama saja karena pemaparan di vidio sangat jelas seperti tatap muka langsung".

Temuan penelitian ini sejalan dengan pendapat Zhang et al.(2006) yang menyatakan bahwa meskipun video e-learning efektif dan mendapat respon yang baik dari mahasiswa dalam menunjang tercapainya tujuan pembelajaran, tetapi tidak dapat diklaim bahwa video lebih unggul jika dibandingkan dengan perkuliahan konvensional secara klasikal. Namun, pendapat Zhang et al.(2006) terjawab melalui rekomendasi yang diuraikan oleh Guo et al.(2014) dalam pembuatan video 


\section{saki}

Studi Akuntansi \& Keuangan Indonesia

pembelajaran agar keunggulan metode konvensional klasikal dapat terkolaborasi di dalam video tutorial praktikum menyebutkan bahwa durasi video lebih pendek lebih menarik yang disesuaikan dengan materi yang dibahas. Materi yang sifatnya teori tentu berbeda jumlah waktu yang dibutuhkan dengan materi yang sifatnya praktik. Rekaman layar persentasi yang dijelaskan seorang instruktur atau pemateri lebih diutamakan dan mendominasi isi video. Peran instruktur atau pemateri dalam video tidak hanya menguraikan suatu tutorial atau teknis kerja tetapi juga dapat memberikan motivasi agar antusiasme peserta secara alami meningkat. Hal yang juga lebih penting untuk diperhatikan dalam pembuatan video adalah keinginan peserta untuk menonton ulang video tersebut. Oleh karena itu, berdasarkan hasil penelitian ini diketahui bahwa jika perkuliahan sudah normal kembali secara tatap muka di kampus pasca covid-19 maka, dosen agar tetap membuat video tutorial praktikum yang telah diajarkan atau dipraktikkan di kampus, sehingga mahasiswa dapat mempelajarinya kembali tanpa dibatasi ruang dan waktu.

\section{Kesimpulan, Implikasi, dan Keterbatasan}

Kesimpulan penelitian ini menunjukkan bahwa video praktikum melalui YouTube yang dikembangkan peneliti mendapatkan respon yang baik dari mahasiswa sebagai media praktikum yang cocok dan efektif yang diimplementasikan pada saat pandemi Covid-19 dan dapat diimplementasikan media yang sama pasca covid-19. Efektivitas video sebagai media praktikum dapat dilihat dari semangat dan keaktifan mahasiswa dalam mengikuti dan dalam menyimak video yang diberikan dapat dilakukan secara berulang. Adapun faktor-faktor yang mendukung tercapainya efektivitas tersebut seperti; (a) gambar dan animasi yang kreatif serta perpaduan warna yang menarik dan mengisyaratkan informasi yang disampaikan; (b) terdokumentasi sehingga dapat disimak dan dipelajari berulang-ulang secara online dan offline. Faktor-faktor tersebut juga merupakan instrumen yang perlu diperhatikan dalam pembuatan dan implementasi video praktikum berbasis YouTube.

Implikasi penelitian ini untuk menjadi masukan kepada dosen akuntansi agar membuat video tutorial praktikum yang diupload via YouTube meskipun, setelah semua kondisi kembali normal pasca 


\section{saki}

Studi Akuntansi \& Keuangan Indonesia

covid-19 dimana perkuliahan dan praktikum dilakukan secara tatap muka di kampus sehingga mahasiswa dapat mempelajari kembali kegiatan praktikum yang telah dilakukan di jam perkuliahan.

Keterbatasan pada penelitian ini adalah menganalisis secara kualitatif dan hanya menganalisis pembelajaran elektronik melalui YouTube, oleh karena itu sebagai rekomendasi penelitian berikutnya agar dapat dikembangkan dengan menggunakan jenis penelitian kuantitatif dan dengan mengkombinasikan beberapa media pembelajaran berbasis digital.

\section{Daftar Pustaka}

Afiyanti, Y. (2008). Validitas dan Reliabilitas dalam Penelitian Kualitatif. Jurnal Keperawatan Indonesia, 12(2), 137-141. Available at: http://dx.doi.org/10.7454/jki.v12i2.212.

Agustina, Merry. 2013. Pemanfaatan E-Learning sebagai Media Pembelajaran. Seminar Nasional Aplikasi Teknologi Informasi (SNATI). Available at: https://journal.uii.ac.id/Snati/article/view/3064

Ardiansyah. (2020). Implementasi Akuntabilitas melalui Evaluasi Online di Era Revolusi Industri 4.0. Jurnal Maneksi: Management Ekonomi dan Akuntansi, 9(1), 355-361. Available at: https://doi.org/10.31959/jm.v9i1.401

Bachri, B.S. (2010). Meyakinkan Validitas Data Melalui Triangulasi pada Penelitian Kualitatif. Jurnal Teknologi Pendidikan. 10(1):46-62. Available at: http://yusuf.staff.ub.ac.id/files/2012/11/meyakinkan-validitasdata-melalui-triangulasi-pada-penelitian-kualitatif.pdf

Chariri, A. (2009). Landasan Filsafat dan Metode Penelitian Kualitatif. Pp. 1-27 in Workshop Metodologi Penelitian Kuantitatif dan Kualitatif. Semarang: Laboratorium Pengembangan Akuntansi (LPA), Fakultas Ekonomi Universitas Diponegoro, 31 Juli-1 Agustus. Available at: http://eprints.undip.ac.id/577/

Darmayasa, I.N., \& Aneswari, Y.R. (2015). Paradigma Interpretif pada Penelitian Akuntansi Indonesia. Jurnal Akuntansi Multiparadigma, 6(3):350-361. http://dx.doi.org/10.18202/jamal.2015.12.6028

Djasuli, M. (2017). Paradigma Interpretif pada Riset Akuntansi (Sebuah Opini: Peneliti Pemula Tidak Terjebak Dalam Penelitian Minimalis Akuntansi). Jurnal Pamator. 10(2):97-106. https://doi.org/10.21107/pamator.v10i2.4143

Dewi, L., Kharisma, A.S. \& Asy'ari, A.N. (2020). Evaluasi Tingkat Penerimaan E-Learning pada Mahasiswa Bidang Keilmuan Sosial Dan Teknik Dengan Technology Acceptance Model (TAM). Jurnal Pendidikan Akuntansi Indonesia, 18(1), 01-11. Available at: http://dx.doi.org/10.21831/jpai.v18i1.27336.

Eastman, J.K., Iyer, R. \& Reisenwitz, T.H. (2008). The Impact Of Unethical Reasoning on Different Types of Academic Dishonesty: An Exploratory Study. Journal of College Teaching \& Learning (TLC), 5(12), 07-16. Available at: http://dx.doi.org/10.19030/tlc.v5i12.1211.

Aydin, I. E. \& Gumus, S. (2016). Sense of classroom community and team development process in online learning. Turkish Online Journal of Distance Education, 17(1), 60-77. Available at: http://dx.doi.org/10.17718/tojde.09900. 


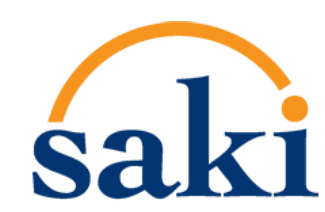

Studi Akuntansi dan Keuangan Indonesia, Vol. 3, No. 2, 2020 | E-ISSN: 2654-6221

Studi Akuntansi \& Keuangan Indonesia

Guo, P.J., Kim, J. \& Rubin, R. (2014). How Video Production Affects Student Engagement: An Empirical Study of MOC Videos. Proceedings of the first ACM conference on Learning @ scale conference - L@S '14. Available at: http://dx.doi.org/10.1145/2556325.2566239.

Hartono, A. (2012). Multi Paradigma Dalam Penelitian Akuntansi; Suatu Tinjauan Konsep. Jurnal Ekulilibrium, 10(1):59-69. http://dx.doi.org/10.24269/ekuilibrium.v7i1.29

Hutagalung, T.B., \& Utomo, D.C. (2017). Meta-Analisis Variasi Penelitian Dari Peneliti Akuntansi Di Indonesia. Diponegoro Journal Of https://ejournal3.undip.ac.id/index.php/accounting/article/view/18688

Irianto, O. (2019). Implementasi Model Pembelajaran STAD Berbantuan LKM untuk Meningkatkan Hasil Belajar Akuntansi Sektor Publik. JPEK (Jurnal Pendidikan Ekonomi dan Kewirausahaan), 3(1), 4460. Available at: http://dx.doi.org/10.29408/jpek.v3i1.1386.

Jailani, M.S. (2013). Ragam Penelitian Qualitative (Ethnografi, Fenomenologi, Grounded Theory, Dan Studi Kasus). Edu-Bio, (4), 41-50.

Kesuma, A.T. (2014). Efektivitas Model Pembelajaran Satus pada Mata Pelajaran Akuntansi Usaha Dagang. Jurnal Pendidikan Ekonomi Dinamika Pendidikan, IX(2), 148-158. https://doi.org/10.15294/dp.v9i2.4890

Kirana, R.W.C. \& Susilowibowo, J. (2020). Pengembangan Bahan Ajar E-Book Praktikum Akuntansi Perusahaan Dagang Berbasis Scientific Approach Sebagai Sumber Belajar Alternatif. Jurnal Pendidikan Akuntansi Indonesia, 18(1), 80-90. Available at: http://dx.doi.org/10.21831/jpai.v18i1.32292.

Latifah, L., \& Susilowati, N. (2011). Inovasi Pembelajaran Akuntansi Berbasis Blended Learning. Jurnal Pendidikan Ekonomi Dinamika Pendidikan, VI(2), 222-232. Available at: https://doi.org/10.15294/dp.v6i2.5113

Luhsasi, D.I. \& Sadjiarto, A. (2017). YouTube: Trobosan Media Pembelajaran Ekonomi Bagi Mahasiswa. Jurnal Ekonomi Pendidikan dan Kewirausahaan, 5(2), 219-229. Available at: http://dx.doi.org/10.26740/jepk.v5n2.p219-229.

Mischel, L.J. (2018). Watch and Learn? Using EDpuzzle to Enhance the Use of Online Videos. Management Teaching Review, 4(3), 283-289. Available at: http://dx.doi.org/10.1177/2379298118773418.

Nurhayati. (2015). Melukiskan Akuntansi dengan Kuas Interpretif. Bisnis: Jurnal Bisnis dan Manajemen Islam. 3(1):174-191. http://dx.doi.org/10.21043/bisnis.v3i1.1481

Nurcahyo, W., Agustina, Y. \& Efriadi, A.R. (2019). Model Perancangan Pembelajaran Blended Mata Kuliah Keilmuan Akuntasi Di ITB-AD Jakarta. JTP - Jurnal Teknologi Pendidikan, 21(2), 179-199. Available at: http://dx.doi.org/10.21009/jtp.v21i2.11338.

Rotellar, C. \& Cain, J. (2016). Research, Perspectives, and Recommendations on Implementing the Flipped Classroom. American Journal of Pharmaceutical Education, 80(2), 1-9. Available at: http://dx.doi.org/10.5688/ajpe80234.

Ruski, R. \& Sholeh, Y. (2019). Pembelajaran Project Based Learning dengan Menggunakan Sosial Media YouTube Pada Mata Kuliah Media Pembelajaran. JPEK (Jurnal Pendidikan Ekonomi dan Kewirausahaan), 3(2), 151-158. Available at: http://dx.doi.org/10.29408/jpek.v3i2.1667.

Samosir, F.T., Pitasari, D.W., \& Tjahjono, P.E. (2019). Efektifitas Pemanfaatan YouTube Melaui Video Online Sebagai Media Pembelajaran oleh Mahasiswa (Studi Di Fakultas Fisip Universitas Bengkulu). Record and Library Journal, 4(2), 81-91. Available at: http://dx.doi.org/10.20473/rlj.v4-i2.2018.81-91. 


\section{saki}

Studi Akuntansi \& Keuangan Indonesia

Taufiq, M. (2015). Pengaruh Pengetahuan Awal Akuntansi dan Efikasi Diri terhadap Tingkat Pemahaman Akuntansi Melalui Minat Belajar pada Mahasiswa Jurusan Akuntansi Universitas PGRI Adi Buana Surabaya. Jurnal Ekonomi Pendidikan Dan Kewirausahaan, 3(2), 181-196. Available at: http://dx.doi.org/10.26740/jepk.v3n2.p181-196.

Titisari, K.H., Wijayanti, A., \& Chomsatun, Y. (2013). Model Pembelajaran Akuntansi untuk Meningkatkan Kompetensi Mahasiswa. Jurnal Buletin Studi Ekonomi, 18(2), 126-135. Available at: https://ojs.unud.ac.id/index.php/bse/article/view/7789

Yusri, Rosida. A., Jufri., \& R. M. (2018). Efektivitas Penggunaan Media YouTube Berbasis Various Approaches dalam Meningkatkan Motivasi Belajar Bahasa Inggris. Eralingua: Jurnal Pendidikan Bahasa Asing dan Sastra, 2(2), 77-82. Available at: http://dx.doi.org/10.26858/eralingua.v2i2.6760.

Zhang, D., Zhou, L., Briggs, R. O., \& Nunamaker Jr, J. F. (2006). Instructional video in e-learning: Assessing the impact of interactive video on learning effectiveness. Information \& management, 43(1), 15-27. Available at: http://dx.doi.org/10.1016/j.im.2005.01.004. 
Studi Akuntansi \& Keuangan Indonesia

\section{Lampiran}

\section{Kuesioner 1}

Berikut ini kuesioner yang dibagikan kepada mahasiswa melalui google form.

\section{KUESIONER 1}

Silahkan berikan jawaban anda yang JUJUR DAN SESUAI kondisi anda tanpa ada rasa tekanan dalam bentuk apapun.

1. Saat ini anda tinggal di mana?

○ Di Kota Ambon

- Di luar Kota Ambon

2. Jika tinggal di Kota Ambon, Saudara tinggal dimana?

- Rumah Orang Tua

- Rumah Saudara

- Rumah Sendiri

- Kos

- Lainnya

3. Perangkat/alat yang anda gunakan?
○ Notebook
- Tablet
- Handphone
- Desktop / Komputer
$\circ \quad$ Lainnya

4. Koneksi internet yang anda gunakan?
○ Wifi
$\circ \quad$ Internet HP
- Tethering HP Sejawat
- Jaringan LAN
- Lainnya

5. Seberapa siap fasilitas internet anda
- Siap - Internet Cepat
- Siap - Kouta Cukup
- Kurang Siap - Jaringan Internet Tidak Stabil
- Kurang Siap - Kouta Tidak Cukup
- Kurang Siap - Jaringan Internet Tidak Stabil dan Kouta Tidak Cukup
$\circ \quad$ Lainnya

6. Apakah anda pernah kuliah Online sebelum masa pandemi Covid-19

○ Pernah

- Tidak Pernah

7. Menurut anda apa saja keunggulan kuliah online yang anda rasakan selama ini untuk semua mata kuliah? (silahkan ceklik pilihan-pilihan dibawah ini yang sesuai, boleh lebih dari satu)

○ Tidak perlu ke kampus

- Lebih fleksibel dan relaks

- Pengalaman baru

- Materi terdokumentasi dan dapat dipelajari kembali 


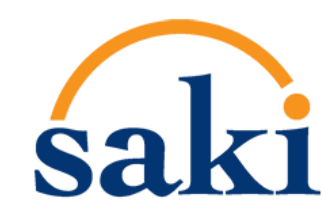

Studi Akuntansi \& Keuangan Indonesia
- Efisiensi waktu dan biaya
- Lebih berani bertanya dan mengajak diskusi
$\circ \quad$ Lainnya

8. Menurut anda apa saja kekurangan kuliah online yang anda rasakan selama ini untuk semua mata kuliah? (silahkan ceklik pilihan-pilihan dibawah ini yang sesuai, boleh lebih dari satu)
○ Jaringan internet kadang tidak stabil
- Sering diganti tugas online
- Beban tugas yang berlebihan/tugas yang banyak
- Dosen kurang interaktif dan komunikatif
- Jadwal kuliah sering ganti
- Lainnya

9. Sebutkan aplikasi perkuliahan online yang anda gunakan untuk semua mata kuliah (silahkan ceklik pilihan-pilihan dibawah ini yang anda gunakan, boleh lebih dari satu)

$\begin{array}{ll}\circ & \text { Vclass } \\ \circ & \text { Google classroom } \\ \circ & \text { Webinar } \\ \circ & \text { Zoom } \\ \circ & \text { Skype } \\ \circ & \text { Webex } \\ \circ & \text { Facebook } \\ \circ & \text { YouTube } \\ \circ & \text { Edmodo } \\ \circ & \text { WAG } \\ \circ & \text { Google Formulir } \\ \circ & \text { Lainnya }\end{array}$

10. Menurut anda kuliah online dibandingkan dengan kuliah kelas/tatap muka langsung?

- Kuliah tata muka (langsung) lebih baik

○ Kuliah online lebih baik

11. Berapa biaya yang Saudara keluarkan untuk pembelajaran daring per pekan/bulan, sebutkan ? (Contoh: Rp. 30.000,-/pekan atau Rp200.000,-/bulan atau Rp0,- karena wifi/kouta gratis)

\section{Kuesioner 2}

Berikut ini angket yang dibagikan kepada mahasiswa melalui google form.

\section{Kuesioner 2}

Pertanyaan Khusus Mata Kuliah Akuntansi Dagang, Dosen: Bapak Ardiansyah, S.E., M.Ak. Semua pertanyaan ini tidak akan mempengaruhi penilaian baik atau tidak baik untuk anda.

Oleh karena itu, silahkan berikan jawaban anda yang JUJUR DAN SESUAI HATI NURANI anda tanpa ada rasa tekanan dalam bentuk apapun.

- Seberapa baik anda memahami materi yang disampaikan dosen melalui video di YouTube, berikan jawaban anda dengan JUJUR dan alasannya? 


\section{saki}

Studi Akuntansi \& Keuangan Indonesia

- Apakah penjelasan dosen melalui video di YouTube dapat anda mengerti, berikan jawaban anda dengan JUJUR dan alasannya?

- Seberapa baik kualitas penyajian materi dosen melalui video di YouTube, berikan jawaban anda dengan JUJUR dan alasannya?

- Mana yang lebih mudah anda pahami, mendengarkan langsung penjelasan dosen di kelas atau melalui video di YouTube, berikan jawaban anda dengan JUJUR dan alasannya ?

- Menurut anda Apa kelebihan materi video pembelajaran di YouTube Mata Kuliah Akuntansi Dagang, berikan jawaban anda dengan JUJUR dan alasannya ?

- Menurut anda Apa kelemahan materi video pembelajaran di YouTube Mata Kuliah Akuntansi Dagang, berikan jawaban anda dengan JUJUR dan alasannya ?

- Apa saran/masukan anda untuk pembuatan video pembelajaran audio visual di YouTube yang lebih baik dan mudah dimengerti mahasiswa yang seperti anda, berikan jawaban anda dengan JUJUR dan alasannya?

\section{Media YouTube}

Berikut ini playlists dan link untuk akses video melalui channel YouTube yang digunakan sebagai salah satu media dalam praktikum akuntansi.

\begin{tabular}{|l|l|l|}
\hline No & \multicolumn{1}{|c|}{ Playlists } & \multicolumn{1}{c|}{ Link } \\
\hline 1 & Persamaan Dasar Akuntansi & $\begin{array}{l}\text { https://www.YouTube.com/playlist?list=PLDU0B8Yb6- } \\
\text { y214hfTaMtU1UVwTLBnGVL2 }\end{array}$ \\
\hline 2 & Jurnal Umum & $\begin{array}{l}\text { https://YouTube.com/playlist?list=PLDU0B8Yb6- } \\
\text { y13mQ83rp2IbZfLtcNzedF8 }\end{array}$ \\
\hline 3 & Jurnal Khusus & $\begin{array}{l}\text { https://www.YouTube.com/playlist?list=PLDU0B8Yb6- } \\
\text { y3zlICB1Q9vrKvtT5brFUkF }\end{array}$ \\
\hline 4 & HPP, LIFO, FIFO, Periodik & $\begin{array}{l}\text { https://www.YouTube.com/playlist?list=PLDU0B8Yb6- } \\
\text { ylrZTFy87nESfXCSNxiQ6uf }\end{array}$ \\
\hline
\end{tabular}

